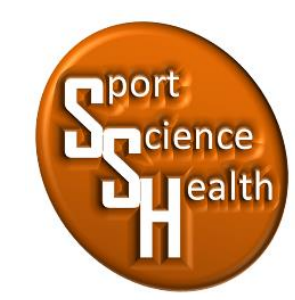

ISSN 2715-3886

\title{
Survei Keterampilan Teknik Dasar Lay Up Dan One Hand Set Shot Pada Siswa Peserta Ekstrakurikuler Bolabasket Sekolah Menengah Atas
}

\author{
Kharisma Yudha Eka Pratama ${ }^{1 *}$, Usman Wahyudi², Gema Fitriady ${ }^{3}$ \\ 1,2,3 Jurusan Pendidikan Jasmani, Kesehatan dan Rekreasi, Fakultas IImu Keolahragaan, \\ Universitas Negeri Malang, Jalan Semarang No 5, Malang, Jawa Timur, 65145, Indonesia \\ *Penulis koresponden: kharidyudha@gmail.com
}

Artikel diterima: 1 Februari 2021; direvisi: 18 Februari 2021; disetujui: 22 Februari 2021

\begin{abstract}
The purpose of this study was to determine the level of basic technical skills of lay up and one hand set shot of basketball extracurricular members at SMAN 1 Turen Malang Regency. This research is a quantitative descriptive study using a survey method. The research subjects were 20 participants. The data analysis technique in this study used the percentage formula. The results showed that the extracurricular participants did the lay up and one hand set shot skills test in the "Enough" category with 13 participants $(65.00 \%)$. Based on the results of the study it can be concluded that the basic technique skills of lay up and one hand set shot of extracurricular basketball participants at SMAN 1 Turen Malang Regency are included in the "Enough" category.
\end{abstract}

Keyword: lay up, one hand set shot, basketball extracurricular

\begin{abstract}
Abstrak: Tujuan dari penelitian ini untuk mengetahui tentang tingkat keterampilan teknik dasar lay up dan one hand set shot peserta ekstrakurikuler bolabasket di SMAN 1 Turen Kabupaten Malang. Penelitian ini ialah penelitian deskriptif kuantitatif menggunakan metode survei. Subjek penelitian sebanyak 20 peserta. Teknik analisis data dalam penelitian menggunakan rumus persentase. Hasil penelitian menunjukkan bahwa peserta ekstrakurikuler dalam melakukan tes keterampilan lay up dan one hand set shot pada kategori "Cukup" dengan 13 peserta $(65,00 \%)$. Berdasarkan hasil penelitian dapat disimpulkan bahwa kemampuan teknik dasar lay up dan one hand set shot peserta ekstrakurikuler bolabasket SMAN 1 Turen Kabupaten Malang termasuk dalam kategori "Cukup".
\end{abstract}

Kata kunci: lay up, one hand set shot, ekstrakurikuler bolabasket

\begin{abstract}
PENDAHULUAN
Permainan bolabasket merupakan suatu permainan yang dimainkan oleh 2 regu putra ataupun putri, yang masing-masing regu terdiri dari berdasarkan 5 orang pemain \& bertujuan untuk mencetak angka sebanyakbanyaknya dengan cara memasukkan bola ke basket/keranjang lawan dan mencegah pemain lawan untuk menciptakan angka/memasukkan bola ke basket/keranjang regu kita (Sumaryoto \& Sopembri, 2017). Menurut Yusmawati (2014) permainan bolabasket adalah permainan yang dilakukan secara beregu dan kemenangan dalam suatu tim ditentukan oleh selisih jumlah point. Sedangkan menurut Tsang et al. (2014) basket adalah olahraga yang dinamis dimana para pemain membutuhkan koordinasi mata, tangan dan kontrol postur yang
\end{abstract}


sangat baik untuk menangkap, melempar, menembak, melompat, berputar, dan memutar gerakan tanpa cacat di lingkungan yang menantang. Dalam permainan bolabasket baku, setiap tim memiliki lima pemain di lapangan. Secara tradisional, posisi dan peran pemain bolabasket ditentukan oleh: point guard (1 spot; menjadi pemimpin lantai dan distributor bola), shooting guard (2 spot; mencetak dari perimeter serta melalui penetrasi ke keranjang), small forward ( 3 spot; bermain baik di dalam maupun di luar), power forward (4 spot; membuat pukulan lompatan midrange, mencetak gol di tiang rendah, rebound dan melindungi keranjang) dan center ( 5 spot; mencetak di sekeliling keranjang, rebound dan memblokir tembakan) (Teramoto \& Cross, 2018).

Dari waktu ke waktu peraturan permainan bolabasket sudah mengalami banyak perubahan \& teknik dari permainan bolabasket yaitu mengumpan (passing) menerima bola, menggiring (dribbling), menembak (shooting), latihan olah kaki (footwork), \& Pivot. Menurut Polozov \& Akhmetzyanov (2019) menyebutkan bahwa elemen-elemen dalam permainan bolabasket adalah assist, tembakan dua poin, rebound, steal, tembakan tiga poin, lemparan bebas, terobosan, pilih dan putar, tembakan yang diblokir. Menurut Rahim (2015), shooting (menembak) merupakan keahlian yang sangat penting pada olahraga bolabasket. Teknik dasar seperti operan (passing), menggiring (dribbling), bertahan (defense), \& rebounding membantu tim dalam memperoleh peluang mendapatkan skor \& harus diakhiri dengan melakukan tembakan ke arah ring, tentu saja salah satunya dengan menggunakan tembakan one hand set shot. Sedangkan menurut Prasetya (2012), lay up merupakan teknik dasar yang wajib dikuasai oleh pemain bolabasket sebab teknik ini merupakan penentu dalam setiap pertandingan bolabasket. Sasaran akhir dalam permainan bolabasket adalah mencetak angka. Untuk dapat mencetak angka, pemain bolabasket harus bisa menguasai teknik lay up dengan baik. Menurut Nathial (2014) dalam melakukan tembakan lay up ini mengharuskan pemain untuk bergerak ke arah keranjang, dan untuk 'meletakkan' bola 'ke atas' dan ke dalam keranjang, atau dari papan belakang (versi papan bawah yang bebas dan licin disebut gulungan jari). Menggunakan adanya penelitian sebelumnya tersebut dapat dikatakan bahwa teknik dasar lay up \& one hand set shot merupakan teknik yang penting dan wajib dikuasai oleh setiap pemain dalam permainan bolabasket.

Ekstrakurikuler adalah suatu kegiatan pembelajaran yang dilakukan diluar jam pelajaran sekolah yang dilakukan baik di sekolah ataupun di luar sekolah (Hamsa \& Hartoto, 2015). Menurut Lestari (2016) yaitu kegiatan ekstrakurikuler merupakan wahana dalam mengembangkan bakat dan minat siswa diluar jam pelajaran. Sedangkan menurut Kentiba \& Asgedom (2018) kegiatan ekstrakurikuler adalah kegiatan siswa yang diselenggarakan berdasarkan sekolah yang biasanya tidak memiliki kredit akademik. Masa kanak-kanak tengah, mulai dari usia 7 hingga 12 adalah fase usia yang jelas berbeda dari tahun-tahun masa kanak-kanak dan masa remaja. Tugas perkembangan utama yang mendefinisikan tahap ini termasuk pembentukan hubungan teman sebaya, perolehan perilaku yang sesuai secara sosial, dan membentuk dasar untuk prestasi akademik. Keterampilan ini dapat dikembangkan dalam kegiatan ekstrakurikuler, yang biasanya menawarkan pengalaman kerja tim dan mendukung pengembangan banyak keterampilan sosial, kognitif, dan fisik.

Berdasarkan hasil observasi penelitian pada hari Rabu tanggal 23 Oktober 2019 pukul 14.00 WIB yang dilakukan dengan cara dokumentasi video dalam pertandingan yang diselenggarakan di SMAN 1 Lawang, permainan yang dimainkan tim bolabasket SMAN 1 Turen Kabupaten Malang sudah cukup bagus karena berhasil menang dengan point 25-15. Akan tetapi dalam pertandingan tersebut pemain lebih sering melakukan kesalahan dalam melakukan lay up shot dan one hand set shot. Dalam melakukan lay up shot kesalahan terjadi karena setelah melakukan langkah lay up pemain hanya mengarahkan bola ke arah ring dengan posisi tangan yang belum benar sehingga bola tidak bisa masuk ke dalam ring basket. Sedangkan pemain yang melakukan tembakan one hand set shot kesalahan terjadi karena siku pemain masih terbuka menyamping dan belum di posisi yang benar sudah melakukan tembakan sehingga angka untuk tim jadi terbuang sia-sia. Karena kesalahan tersebut pemain lawan dapat memanfaatkan kekurangan siswa SMAN 1 Turen Kabupaten Malang yang tidak bisa memasukkan bola saat lay up dan one hand set shot, sehingga pemain lawan dapat melakukan serangan balik ke daerah pertahanan siswa SMAN 1 Turen Kabupaten Malang untuk mencetak angka. Berdasarkan hasil wawancara kepada pelatih bolabasket di SMAN 1 Turen Kabupaten Malang, terdapat beberapa permasalahan yang terdapat pada para pemainnya. Menurut penjelasan pelatih, faktor yang mengakibatkan pemain melakukan kesalahan dalam lay up dan one hand set shot adalah dikarenakan mental pemain saat pertandingan dan faktor lapangan. Tidak hanya faktor-faktor tersebut, terdapat faktor lain yaitu kurangnya frekuensi latihan dalam melakukan teknik tersebut. Latihan ekstrakurikuler bolabasket hanya dilakukan seminggu 1 kali. Latihan keterampilan teknik dasar secara khusus sangat diperlukan bagi peserta 
ekstrakurikuler bolabasket SMAN 1 Turen Kabupaten Malang agar teknik dasar yang menjadi pondasi dalam bermain bolabasket dapat ditingkatkan.

Berdasarkan hasil penelitian sebelumnya yang diteliti oleh Prasetia (2015) yang berjudul "Tingkat Kemampuan Lay Up Shoot pada Siswa yang Mengikuti Ekstrakurikuler Bolabasket di SMK Leonardo Klaten", dapat disimpulkan bahwa tingkat keterampilan lay up siswa ekstrakurikuler bolabasket di SMK Leonardo Klaten tergolong sedang. Hasil ini dapat diketahui bahwa siswa yang mendapatkan skor tertinggi adalah 12 dan siswa yang mendapatkan skor terendah adalah 5. Data yang diperoleh pada penelitian tersebut, 2 siswa (8\%) dinyatakan sangat baik, 6 siswa (24\%) dinyatakan baik, 10 siswa (40\%) dinyatakan sedang, 5 siswa (20\%) dinyatakan rendah, \& 2 siswa (8\%) dinyatakan sangat rendah.

Berdasarkan hasil penelitian sebelumnya yang diteliti oleh Febrianto (2013) yang berjudul "Survei Hasil One Hand Set Shoot Dalam Permainan Bolabasket Pada Pemain Putra Kelompok Usia 12-15 Tahun Klub Basket Sehati Kota Semarang", didapat hasil bahwa tingkat keterampilan one hand set shot pemain putra usia 12-15 tahun klub bolabasket Sehati Kota Semarang tergolong kurang. Hasil ini dapat diketahui dari 20 orang, data yang diperoleh adalah 1 pemain (5\%) berhasil melakukan 25 kali shoot dengan persentase keberhasilan antara 84\% - 100\% dan digolongkan kedalam kriteria sangat baik, 2 pemain (10\%) berhasil melakukan 25 kali shoot dengan persentase keberhasilan antara $68 \%$ - $84 \%$ dan digolongkan kedalam kriteria baik, 8 pemain (40\%) berhasil melakukan 25 kali shoot dengan persentase keberhasilan antara 52\% - 68\% dan digolongkan kedalam kriteria cukup, 9 pemain (45\%) berhasil melakukan 25 kali shoot dengan persentase keberhasilan antara $36 \%-52 \%$ dan digolongkan kedalam kriteria tidak baik, dan tidak ada seorang pemain-pun yang termasuk dalam kriteria sangat tidak baik.

Sedangkan dalam penelitian yang diteliti oleh Apriani (2011) yang berjudul "Survei Tingkat Kemampuan Lay Up Dan One Hand Set Shoot Dalam Permainan Bolabasket Pada Kegiatan Ekstrakurikuler Bolabasket Putri SMA N 1 Banjarnegara Tahun 2010/2011", didapat hasil bahwa tingkat keterampilan lay up siswa ekstrakurikuler bolabasket Putri SMAN 1 Banjarnegara tergolong baik. Hasil ini dapat diketahui dari data yang diperoleh dalam penelitian tersebut, yaitu 4 siswi (27\%) dinyatakan sangat baik, 9 siswi $(60 \%)$ dinyatakan baik, 1 siswa (7\%) dinyatakan cukup baik, 1 siswa (7\%) dinyatakan kurang, dan 0 siswa (0\%) dinyatakan sangat kurang. Serta tingkat keterampilan one hand set shot siswa ekstrakurikuler bolabasket Putri SMAN 1 Banjarnegara tergolong kurang. Hasil ini dapat diketahui dari data yang diperoleh dalam penelitian tersebut, 0 siswi (0\%) dinyatakan sangat baik, 2 siswi (13\%) dinyatakan baik, 5 siswa (33\%) dinyatakan cukup baik, 7 siswa $(47 \%)$ dinyatakan kurang, dan 1 siswa $(7 \%)$ dinyatakan sangat kurang.

Berdasarkan latar belakang di atas, untuk mendapatkan hasil yang lebih baik dalam melakukan teknik dasar tersebut, maka peneliti memberikan solusi untuk mengetahui seberapa terampil siswa ekstrakurikuler bolabasket SMAN 1 Turen Kabupaten Malang dalam memasukkan bola dengan menggunakan teknik lay up dan one hand set shot, maka peneliti tertarik untuk melakukan penelitian yang berjudul yaitu "Survei Tingkat Keterampilan Lay Up dan One Hand Set Shot pada Ekstrakurikuler Bolabasket di SMAN 1 Turen Kabupaten Malang".

\section{METODE}

Rancangan dalam penelitian ini menggunakan jenis penelitian deskriptif kuantitatif dan dalam penelitiannya peneliti menggunakan rancangan survei. Metode penelitian yang digunakan pada penelitian ini adalah metode survei, dengan teknik pengambilan data menggunakan tes dan pengukuran. Subjek dalam penelitian ini adalah peserta didik ekstrakurikuler bolabasket SMAN 1 Turen Kabupaten Malang yang berjumlah 20 peserta didik yang terdiri dari 15 putra dan 5 putri. Instrumen penelitian yang akan digunakan dalam pengumpulan data adalah dengan menggunakan tes yang berupa tes keterampilan lay up dan one hand set shot pada ekstrakurikuler bolabasket di SMAN 1 Turen Kabupaten Malang. Tes keterampilan lay up dan one hand set shot ini bertujuan untuk mengukur tingkat kemampuan siswa dalam memasukkan bola ke dalam ring basket dengan menggunakan teknik dasar lay up dan one hand set shot. Tes ini dilakukan di lapangan bolabasket dengan cara melakukan lay up dari tiga tempat yang sudah ditentukan dan melakukan 1 kali percobaan pada tiap-tiap tempat. Serta melakukan tes one hand set shot dari tiga tempat yang sudah ditentukan dan melakukan 1 kali tembakan pada tiap-tiap tempat. Setelah data terkumpul dari hasil pengumpulan data, selanjutnya akan dilaksanakan analisis data. Analisis data yang digunakan pada penelitian ini adalah deskriptif kuantitatif dengan metode analisis perhitungan statistik menggunakan analisis deskriptif persentase. 
Selanjutnya menentukan kategori kriteria penilaian digunakan rumus statistik berdasarkan nilai rata-rata serta standar deviasi (Jamshed, 2014; Kafle, 2013; Leguina, 2015; Van Hoecke, 2016.

Tabel 1. Kategori Penilaian

\begin{tabular}{lll}
\hline NO & RENTANG NORMA & KATEGORI \\
\hline 1 & $\mathrm{M}+1,5 \mathrm{SD} \leq$ & Sangat-Baik \\
\hline 2 & $\mathrm{M}+0,5 \mathrm{SD}<\mathrm{M}+1,5 \mathrm{SD}$ & Baik \\
\hline 3 & $\mathrm{M}-0,5 \mathrm{SD}<\mathrm{M}+0,5 \mathrm{SD}$ & Cukup \\
\hline 4 & $\mathrm{M}-1,5 \mathrm{SD}<\mathrm{M}-0,5 \mathrm{SD}$ & Kurang \\
\hline 5 & $\leq \mathrm{M}-1,5 \mathrm{SD}$ & Sangat-Kurang \\
\hline
\end{tabular}

\section{HASIL}

Berdasarkan-penelitian yang dilakukan melalui proses pengambilan data akan diperoleh hasil tes keterampilan teknik dasar lay up dan one hand set shot pada peserta ekstrakurikuler balabasket di SMAN 1 Turen Kabupaten Malang.

\section{Deskripsi Data}

Dalam penyajian hasil penelitian ini terdapat beberapa unsur yang dihitung, yaitu: nilai rata--rata hitung (mean), standar deviasi (SD), nilai maksimum, dan nilai minimum pada setiap hasil tes keterampilan lay up dan one hand set shot putra, putri dan keseluruhan peserta ekstrakurikuler bolabasket di SMAN 1 Turen Kabupaten Malang. Kemudian data akan dikategorikan sesuai dengan rumus yang ditentukan menjadi lima kategori, yaitu "Baik Sekali", "Baik”, "Cukup”, "Kurang”, dan "Kurang Sekali”.

Tabel 2. Penyajian Data Hasil Tes Keterampilan Lay Up dan One Hand Set Shot Peserta Ekstrakurikuler Bolabasket SMAN 1 Turen Kabupaten Malang

\begin{tabular}{|c|c|c|c|c|c|c|c|}
\hline $\begin{array}{l}\mathbf{N} \\
\mathbf{0}\end{array}$ & Jenis Tes & $\begin{array}{l}\text { Pesert } \\
\text { a }\end{array}$ & Tempat Pelaksanaan & $\begin{array}{l}\text { Mak } \\
\text { s }\end{array}$ & Min & $\begin{array}{l}\text { Me } \\
\text { an }\end{array}$ & SD \\
\hline \multirow{4}{*}{1} & \multirow{4}{*}{ Lay Up } & \multirow{4}{*}{$\begin{array}{l}\text { Seluru } \\
\mathrm{h} \\
\text { Pesert } \\
\mathrm{a}\end{array}$} & Kanan & $\begin{array}{l}119, \\
72\end{array}$ & $\begin{array}{l}49,7 \\
2\end{array}$ & $\begin{array}{l}12, \\
30\end{array}$ & 1,75 \\
\hline & & & Tengah & $\begin{array}{l}127 \\
78\end{array}$ & $\begin{array}{l}67,7 \\
8\end{array}$ & $\begin{array}{l}11 \\
75\end{array}$ & 1,89 \\
\hline & & & Kiri & $\begin{array}{l}140, \\
77\end{array}$ & $\begin{array}{l}60,7 \\
7\end{array}$ & $\begin{array}{l}10, \\
40\end{array}$ & 2,11 \\
\hline & & & Semua Tempat & $\begin{array}{l}380 \\
52\end{array}$ & $\begin{array}{l}210 \\
52\end{array}$ & $\begin{array}{l}34, \\
45\end{array}$ & 4,33 \\
\hline \multirow{4}{*}{2} & \multirow{4}{*}{$\begin{array}{l}\text { One Hand Set } \\
\text { Shot }\end{array}$} & \multirow{4}{*}{$\begin{array}{l}\text { Seluru } \\
\mathrm{h} \\
\text { Pesert } \\
\mathrm{a}\end{array}$} & Kanan & $\begin{array}{l}135 \\
32\end{array}$ & $\begin{array}{l}65,3 \\
2\end{array}$ & $\begin{array}{l}11 \\
75\end{array}$ & 2,15 \\
\hline & & & Tengah & $\begin{array}{l}161 \\
50\end{array}$ & $\begin{array}{l}71,5 \\
0\end{array}$ & $\begin{array}{l}12, \\
3\end{array}$ & 2,54 \\
\hline & & & Kiri & $\begin{array}{l}163 \\
28\end{array}$ & $\begin{array}{l}63,2 \\
8\end{array}$ & $\begin{array}{l}11, \\
8\end{array}$ & 2,53 \\
\hline & & & Semua Tempat & $\begin{array}{l}458 \\
44\end{array}$ & $\begin{array}{l}198, \\
44\end{array}$ & $\begin{array}{l}35, \\
85\end{array}$ & 6,95 \\
\hline
\end{tabular}

Keterangan:

$\begin{array}{ll}\text { Maks } & \text { : Skor-Maksimal } \\ \text { Min } & : \text { Skor-Minimal } \\ \text { Mean } & : \text { Rata-rata- } \\ \text { SD } & : \text { Standar-Deviasi }\end{array}$ 


\section{Hasil Analisis Data}

Penyajian Hasil-Analisis-Data Tes Keterampilan Lay Up Kanan Keseluruhan Peserta

Tabel 3. Distribusi Kelas Interval Tes Keterampilan Lay Up Kanan Keseluruhan Peserta

\begin{tabular}{lllll}
\hline NO & INTERVAL & $\mathrm{F}$ & PERSENTASI \% & KATEGORI \\
\hline 1 & $129,03 \leq$ & 0 & 0,00 & Sangat Baik \\
\hline 2 & $111,48-129,02$ & 5 & 25,00 & Baik \\
\hline 3 & $93,98-111,47$ & 12 & 60,00 & Cukup \\
\hline 4 & $76,48-93,97$ & 1 & 5,00 & Kurang \\
\hline 5 & $\leq 76,47$ & 2 & 10,00 & Sangat Kurang \\
\hline & $\sum$ (Total) & 20 & 100 & \\
\hline
\end{tabular}

Berdasarkan deskripsi data tes lay up kanan keseluruhan peserta pada peserta ekstrakurikuler bolabasket SMAN 1 Turen Kabupaten Malang yang berjumlah 20 siswa maka diperoleh hasil sebagian besar adalah kategori "Cukup". Hal ini dapat dinyatakan dari hasil penelitian dari 20 peserta, 12 peserta mendapatkan nilai kategori "Cukup" dengan persentase 60,00\%. Dapat diperjelas lagi dari hasil tabel yaitu terdapat, 0 peserta mendapat kategori "Sangat Baik" dengan persentase 0,00\%, 5 peserta dalam kategori "Baik" dengan persentase 25,00\%, 1-peserta mendapat kategori-"Kurang" dengan-persentase 5,00\%, dan 2 peserta mendapat kategori "Sangat Kurang" dengan persentase 10,00\%.

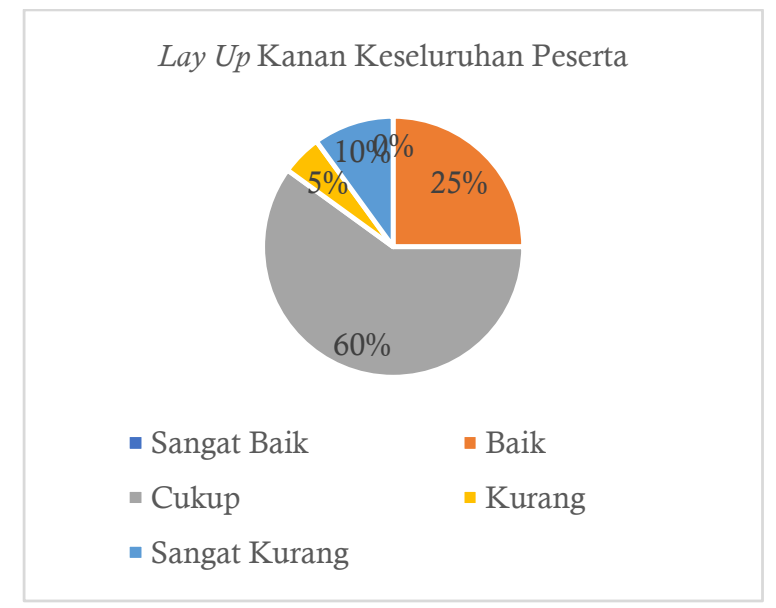

Gambar 1. Diagram Lingkaran Keterampilan Lay Up Kanan Keseluruhan Peserta pada Ekstrakurikuler Bolabasket di SMAN 1 Turen Kabupaten Malang

Penyajian Hasil Analisis Data Tes Keterampilan One Hand Set Shot Kanan Keseluruhan Peserta

Tabel 4. Distribusi Kelas Interval Tes Keterampilan One Hand Set Shot Kanan Keseluruhan Peserta

\begin{tabular}{lllll}
\hline NO & INTERVAL & $F$ & PERSENTASI \% & KATEGORI \\
\hline 1 & $145,08 \leq$ & 0 & 0,00 & Sangat Baik \\
\hline 2 & $123,58-145,07$ & 10 & 50,00 & Baik \\
\hline 3 & $102,08-123,57$ & 6 & 30,00 & Cukup \\
\hline 4 & $80,58-102,07$ & 2 & 10,00 & Kurang \\
\hline 5 & $\leq 80,57$ & 2 & 10,00 & Sangat Kurang \\
\hline & $\sum$ (Total) & 20 & 100 & \\
\hline
\end{tabular}

Berdasarkan deskripsi data tes one hand set shot kanan keseluruhan peserta pada peserta ekstrakurikuler bolabasket SMAN 1 Turen Kabupaten Malang yang berjumlah 20 siswa maka diperoleh hasil sebagian besar adalah kategori "Baik". Hal ini dapat dinyatakan dari hasil penelitian dari 20 peserta, 10 peserta mendapatkan nilai kategori "Baik" dengan persentase 50,00 \%. Dapat diperjelas lagi dari hasil tabel yaitu terdapat, 0 peserta mendapat kategori "Sangat Baik" dengan persentase 0,00\%, 6-peserta mendapat kategori-“Cukup" dengan- 
persentase 30,00\%, 2-peserta mendapat kategori "Kurang" dengan persentase 10,00\%, dan 2 peserta mendapat kategori "Sangat Kurang" dengan persentase 10,00\%.

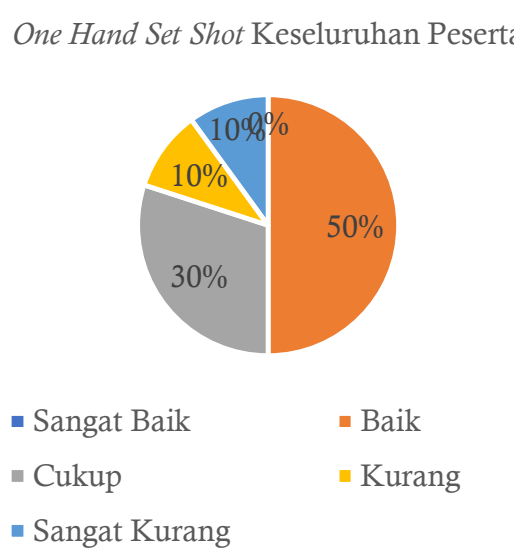

Gambar 2. Diagram-Lingkaran-Keterampilan One Hand Set Shot Kanan Keseluruhan Peserta pada Ekstrakurikuler Bolabasket di SMAN 1 Turen Kabupaten Malang

Penyajian Hasil Analisis Data Tes Keterampilan Lay Up Tengah Keseluruhan Peserta

Tabel 5. Distribusi Kelas Interval Tes Keterampilan Lay Up Tengah Keseluruhan Peserta

\begin{tabular}{lllll}
\hline NO & INTERVAL & $F$ & PERSENTASI \% & KATEGORI \\
\hline 1 & $133,39 \leq$ & 0 & 0,00 & Sangat Baik \\
\hline 2 & $114,74-133,38$ & 7 & 35,00 & Baik \\
\hline 3 & $95,84-114,73$ & 7 & 35,00 & Cukup \\
\hline 4 & $76,94-95,83$ & 5 & 25,00 & Kurang \\
\hline 5 & $\leq 76,93$ & 1 & 5,00 & Sangat Kurang \\
\hline & $\sum$ (Total) & 20 & 100 & \\
\hline
\end{tabular}

Berdasarkan deskripsi data tes lay up tengah keseluruhan peserta pada peserta ekstrakurikuler bolabasket SMAN 1 Turen Kabupaten Malang yang berjumlah 20 siswa maka diperoleh hasil sebagian besar adalah kategori "Baik" dan "Cukup". Hal ini dapat dinyatakan dari hasil penelitian dari 20 peserta, 7 peserta mendapatkan nilai kategori "Baik" dengan persentase $35,00 \%$ dan 7 peserta mendapatkan nilai kategori "Cukup" dengan persentase 35,00\%. Dapat diperjelas lagi dari hasil tabel yaitu terdapat, 0 peserta mendapat kategori "Sangat Baik" dengan-persentase 0,00\%, 5-peserta dalam kategori "Kurang" dengan persentase $25,00 \%$, dan 1 peserta mendapat kategori "Sangat Kurang" dengan persentase 5,00\%.

Lay Up Tengah Keseluruhan Peserta

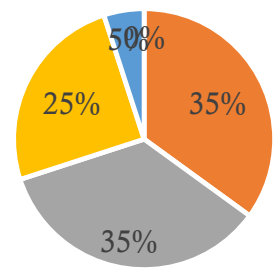

$$
\begin{aligned}
& \text { - Sangat Baik } \quad \text { - Baik } \\
& \text { - Cukup } \\
& \text { - Sangat Kurang }
\end{aligned}
$$

Gambar 3. Diagram Lingkaran Keterampilan Lay Up Tengah Keseluruhan Peserta pada Ekstrakurikuler Bolabasket di SMAN 1 Turen Kabupaten Malang

Penyajian Hasil Analisis Data Tes Keterampilan One Hand Set Shot Tengah Keseluruhan Peserta 
Tabel 6. Distribusi Kelas Interval Tes Keterampilan One Hand Set Shot Tengah Keseluruhan Peserta

\begin{tabular}{lllll}
\hline NO & INTERVAL & F & PERSENTASI \% & KATEGORI \\
\hline 1 & $162,61 \leq$ & 0 & 0,00 & Sangat Baik \\
\hline 2 & $137,21-162,60$ & 8 & 40,00 & Baik \\
\hline 3 & $111,81-137,20$ & 5 & 25,00 & Cukup \\
\hline 4 & $86,41-111,80$ & 5 & 25,00 & Kurang \\
\hline 5 & $\leq 86,40$ & 2 & 10,00 & Sangat Kurang \\
\hline & $\sum$ (Total) & 20 & 100 & \\
\hline
\end{tabular}

Berdasarkan deskripsi data tes one hand set shot tengah keseluruhan peserta pada peserta ekstrakurikuler bolabasket SMAN 1 Turen Kabupaten Malang yang berjumlah 20 siswa maka diperoleh hasil sebagian besar adalah kategori "Baik". Hal ini dapat dinyatakan dari hasil penelitian dari 20 peserta, 8 peserta mendapatkan nilai kategori "Baik" dengan persentase 40,00\%. Dapat diperjelas lagi dari hasil tabel yaitu terdapat, 0 peserta mendapat kategori "Sangat Baik" dengan persentase 0,00\%, 5 peserta dalam kategori "Cukup" dengan persentase $25,00 \%, 5$ peserta mendapat kategori "Kurang" dengan persentase 25,00\%, dan 2 peserta mendapat kategori "Sangat Kurang" dengan persentase 10,00\%.

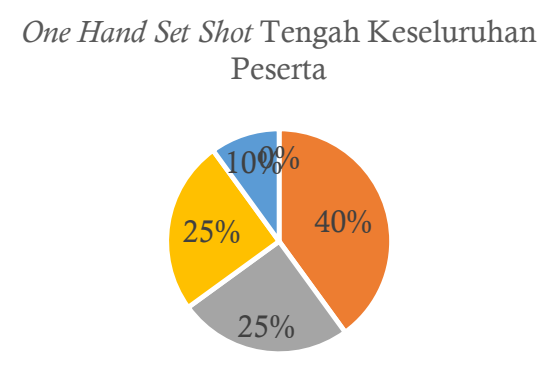

$$
\begin{array}{ll}
\text { - Sangat Baik } & \text { - Baik } \\
\text { - Cukup } & \text { - Kurang } \\
\text { - Sangat Kurang } &
\end{array}
$$

Gambar 4. Diagram Lingkaran Keterampilan One Hand Set Shot Tengah Keseluruhan Peserta pada Ekstrakurikuler Bolabasket di SMAN 1 Turen Kabupaten Malang

Penyajian Hasil Analisis Data Tes Keterampilan Lay Up Kiri Keseluruhan Peserta

Tabel 7. Distribusi Kelas Interval Tes Keterampilan Lay Up Kiri Keseluruhan Peserta

\begin{tabular}{lllll}
\hline NO & INTERVAL & $F$ & PERSENTASI \% & KATEGORI \\
\hline 1 & $136,43 \leq$ & 2 & 10,00 & Sangat Baik \\
\hline 2 & $115,33-136,42$ & 3 & 15,00 & Baik \\
\hline 3 & $94,23-115,32$ & 8 & 40,00 & Cukup \\
\hline 4 & $73,13-94,22$ & 5 & 25,00 & Kurang \\
\hline 5 & $\leq 73,12$ & 2 & 10,00 & Sangat Kurang \\
\hline & $\sum$ (Total) & 20 & 100 & \\
\hline
\end{tabular}

Berdasarkan deskripsi data tes lay up kiri keseluruhan peserta pada peserta ekstrakurikuler bolabasket SMAN 1 Turen Kabupaten Malang yang berjumlah 20 siswa maka diperoleh hasil sebagian besar adalah kategori "Cukup". Hal ini dapat dinyatakan dari hasil penelitian dari 20 peserta, 8 peserta mendapatkan nilai kategori "Cukup" dengan persentase 40,00\%. Dapat diperjelas lagi dari hasil tabel yaitu terdapat, 2 peserta mendapat kategori "Sangat Baik" dengan persentase 10,00\%, 3-peserta dalam-kategori "Baik" dengan-persentase 15,00\%, 5-peserta mendapat kategori "Kurang" dengan persentase $25,00 \%$, dan 2 peserta mendapat kategori "Sangat Kurang" dengan persentase 10,00\%. 


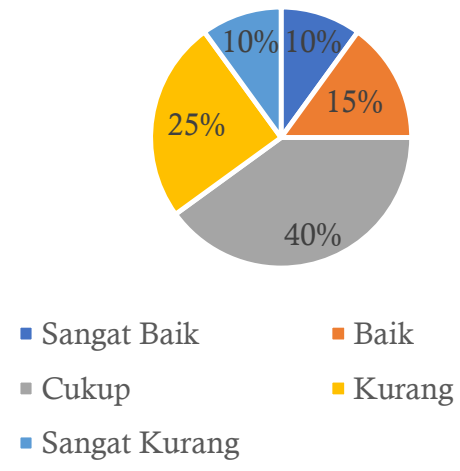

Gambar 5. Diagram Lingkaran Keterampilan Lay Up Kiri Keseluruhan Peserta pada Ekstrakurikuler Bolabasket di SMAN 1 Turen Kabupaten Malang

Penyajian Hasil Analisis Data Tes Keterampilan One Hand Set Shot Kiri Keseluruhan Peserta

Tabel 8. Distribusi Kelas Interval Tes Keterampilan One Hand Set Shot Kiri Keseluruhan Peserta

\begin{tabular}{lllll}
\hline NO & INTERVAL & $\mathrm{F}$ & PERSENTASI \% & KATEGORI \\
\hline 1 & $159,24 \leq$ & 2 & 10,00 & Sangat Baik \\
\hline 2 & $133,94-159,23$ & 2 & 10,00 & Baik \\
\hline 3 & $108,64-133,93$ & 12 & 60,00 & Cukup \\
\hline 4 & $83,34-108,63$ & 2 & 10,00 & Kurang \\
\hline 5 & $\leq 83,33$ & 2 & 10,00 & Sangat Kurang \\
\hline & $\sum$ (Total) & 20 & 100 &
\end{tabular}

Berdasarkan deskripsi data tes one hand set shot kiri keseluruhan peserta pada peserta ekstrakurikuler bolabasket SMAN 1 Turen Kabupaten Malang yang berjumlah 20 siswa maka diperoleh hasil sebagian besar adalah kategori "Cukup". Hal ini dapat dinyatakan dari hasil penelitian dari 20 peserta, 12 peserta mendapatkan nilai kategori "Cukup" dengan persentase 60,00\%. Dapat diperjelas lagi dari hasil tabel yaitu terdapat, 2 peserta mendapat kategori "Sangat Baik" dengan persentase 10,00\%, 2-peserta dalam kategori"Baik" dengan persentase 10,00\%, 2-peserta mendapat kategori "Kurang" dengan persentase 10,00\%, dan 2 peserta mendapat kategori "Sangat Kurang" dengan persentase 10,00\%.

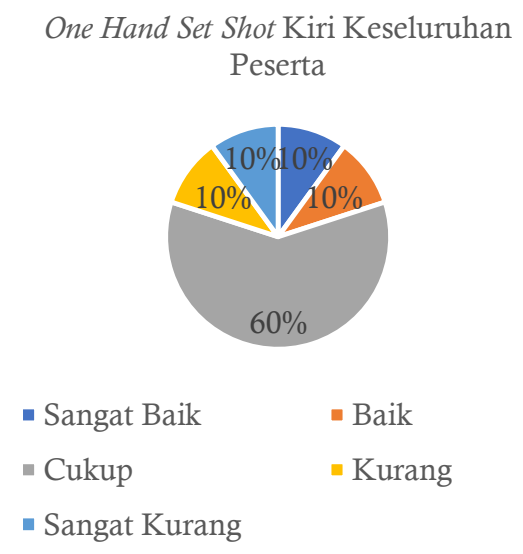

Gambar 6. Diagram Lingkaran Keterampilan One Hand Set Shot Kiri Keseluruhan Peserta pada Ekstrakurikuler Bolabasket di SMAN 1 Turen Kabupaten Malang

Penyajian Hasil Analisis Data Tes Keterampilan Lay Up Keseluruhan Peserta 
Tabel 9. Distribusi Kelas Interval Tes Keterampilan Lay Up Keseluruhan Peserta

\begin{tabular}{lllll}
\hline NO & INTERVAL & $\mathrm{F}$ & PERSENTASI \% & KATEGORI \\
\hline 1 & $379,98 \leq$ & 1 & 5,00 & Sangat Baik \\
\hline 2 & $336,68-379,97$ & 6 & 30,00 & Baik \\
\hline 3 & $293,38-336,67$ & 9 & 45,00 & Cukup \\
\hline 4 & $250,08-293,37$ & 2 & 10,00 & Kurang \\
\hline 5 & $\leq 250,07$ & 2 & 10,00 & Sangat Kurang \\
\hline & $\sum$ (Total) & 20 & 100 & \\
\hline
\end{tabular}

Berdasarkan deskripsi data tes lay up keseluruhan peserta pada peserta ekstrakurikuler bolabasket SMAN 1 Turen Kabupaten Malang yang berjumlah 20 siswa maka diperoleh hasil sebagian besar adalah kategori "Cukup". Hal ini dapat dinyatakan dari hasil penelitian dari 20 peserta, 9 peserta mendapatkan nilai kategori "Cukup" dengan persentase 45,00\%. Dapat diperjelas lagi dari hasil tabel yaitu terdapat, 1-peserta mendapat kategori-“Sangat Baik"-dengan-persentase 5,00\%, 6-peserta dalam kategori-“Baik" dengan-persentase 30,00\%, 2-peserta mendapat kategori-“Kurang"-dengan-persentase 10,00\%, dan 2 peserta mendapat kategori "Sangat Kurang" dengan persentase 10,00\%.

Lay Up Keseluruhan Peserta

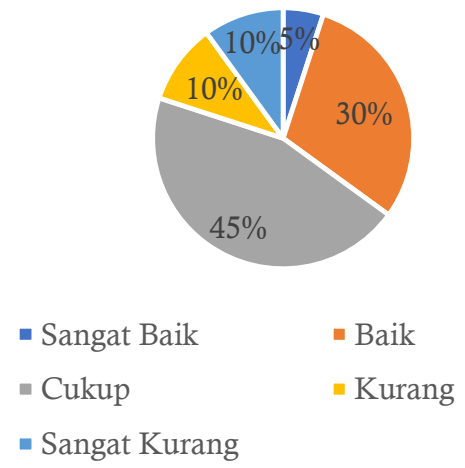

Gambar 7. Diagram Lingkaran Keterampilan Lay Up Keseluruhan Peserta pada Ekstrakurikuler Bolabasket di SMAN 1 Turen Kabupaten Malang

Penyajian Hasil Analisis Data Tes Keterampilan One Hand Set Shot Keseluruhan Peserta

Tabel 10. Distribusi Kelas Interval Tes Keterampilan One Hand Set Shot Keseluruhan Peserta

\begin{tabular}{lllll}
\hline NO & INTERVAL & $F$ & PERSENTASI \% & KATEGORI \\
\hline 1 & $461,20 \leq$ & 0 & 0,00 & Sangat Baik \\
\hline 2 & $391,70-461,19$ & 5 & 25,00 & Baik \\
\hline 3 & $322,20-391,69$ & 11 & 55,00 & Cukup \\
\hline 4 & $252,70-322,19$ & 2 & 10,00 & Kurang \\
\hline 5 & $\leq 252,69$ & 2 & 10,00 & Sangat Kurang \\
\hline & $\sum$ (Total) & 20 & 100 & \\
\hline
\end{tabular}

Berdasarkan deskripsi data tes one hand set shot keseluruhan peserta pada peserta ekstrakurikuler bolabasket SMAN 1 Turen Kabupaten Malang yang berjumlah 20 siswa maka diperoleh hasil sebagian besar adalah kategori "Cukup". Hal ini dapat dinyatakan dari hasil penelitian dari 20 peserta, 11 peserta mendapatkan nilai kategori "Cukup" dengan persentase 55,00\%. Dapat diperjelas lagi dari hasil tabel yaitu terdapat, 0 peserta mendapat kategori "Sangat Baik" dengan persentase $0,00 \%, 5$ peserta dalam kategori "Baik" dengan persentase 25,00\%, 2 peserta mendapat kategori "Kurang" dengan persentase 10,00\%, dan 2 peserta mendapat kategori "Sangat Kurang" dengan persentase 10,00\%. 


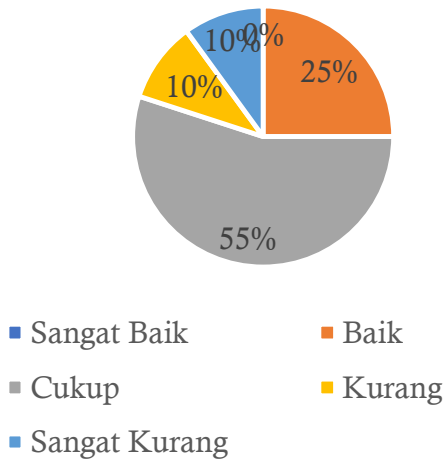

Gambar 8. Diagram Lingkaran Keterampilan One Hand Set Shot Keseluruhan Peserta pada Ekstrakurikuler Bolabasket di SMAN 1 Turen Kabupaten Malang

Penyajian Hasil Analisis Data Tes Keterampilan Lay Up dengan One Hand Set Shot Keseluruhan Peserta

Tabel 11. Distribusi Kelas Interval Tes Keterampilan Lay Up dengan One Hand Set Shot Keseluruhan Peserta

\begin{tabular}{lllll}
\hline NO & INTERVAL & $\mathrm{F}$ & PERSENTASI \% & KATEGORI \\
\hline 1 & $836,27 \leq$ & 1 & 5 & Sangat Baik \\
\hline 2 & $735,27-836,26$ & 3 & 15 & Baik \\
\hline 3 & $634,27-735,26$ & 13 & 65 & Cukup \\
\hline 4 & $533,27-634,26$ & 1 & 5 & Kurang \\
\hline 5 & $\leq 533,26$ & 2 & 10 & Sangat Kurang \\
\hline & $\sum$ (Total) & 20 & 100 & \\
\hline
\end{tabular}

Berdasarkan deskripsi data tes lay up dan one hand set shot keseluruhan peserta pada peserta ekstrakurikuler bolabasket SMAN 1 Turen Kabupaten Malang yang berjumlah 20 siswa maka diperoleh hasil sebagian besar adalah kategori "Cukup". Hal ini dapat dinyatakan dari hasil penelitian dari 20 peserta, 13 peserta mendapatkan nilai kategori "Cukup" dengan persentase 65,00\%. Dapat diperjelas lagi dari hasil tabel yaitu terdapat, 1-peserta mendapat kategori-“Sangat Baik"-dengan persentase 5,00\%, 3-peserta dalam kategori "Baik" dengan persentase 15,00\%, 1-peserta dalam kategori-“Kurang" dengan-persentase 5,00\%, dan 2 peserta mendapat kategori "Sangat Kurang" dengan persentase 10,00\%.

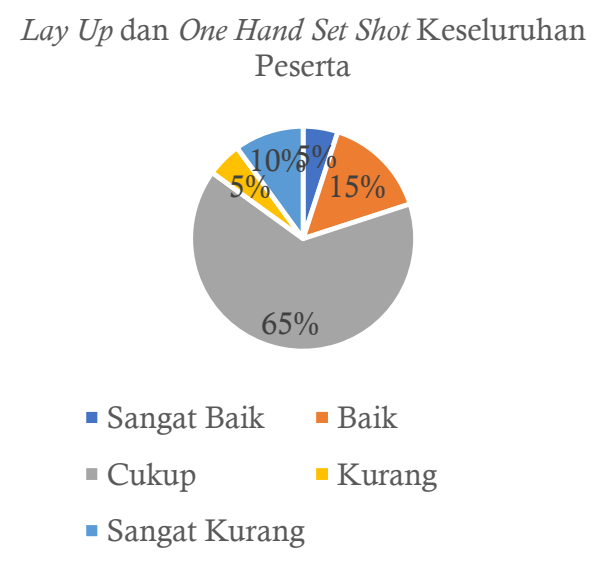

Gambar 9. Diagram Lingkaran Keterampilan Lay Up dan One Hand Set Shot Keseluruhan Peserta pada Ekstrakurikuler Bolabasket di SMAN 1 Turen Kabupaten Malang 


\section{PEMBAHASAN}

Keterampilan lay up dan one hand set shot adalah salah satu teknik dasar permainan bolabasket yang penting \& wajib dapat dikuasai oleh setiap peserta ekstrakurikuler bolabasket. Gerakan lay up merupakan usaha memasukkan bola yang dilakukan dari jarak dekat yang sebelumnya didahului dengan dribble kemudian melangkah dua kali dan dilanjutkan memasukkan bola ke arah ring. Sedangkan one hand set shot merupakan usaha memasukkan bola yang dilakukan dengan menembakkan bola ke arah ring dengan menggunakan satu tangan sebagai pendorong.

Beberapa ahli menjelaskan bahwa shooting merupakan suatu keterampilan teknik dasar yang paling penting. Untuk keterampilan ini, dibutuhkan latihan-latihan yang banyak sekali. Selain ada teknik memegang bola, melempar, menggiring, menangkap, dan rebound, menembak adalah hal yang diperlukan dalam permainan bolabasket untuk memperoleh kemenangan (Edwards et al., 2018; Okazaki, Rodacki, \& Satern, 2015; Tobalina, Calleja-GonzÁlez, De Santos, FernÁndez-López, \& Arteaga-Ayarza, 2013; Trojian et al., 2013).

Dalam penelitian ini peneliti tidak hanya menghitung keseluruhan peserta, tetapi juga berdasarkan kelompok putra dan putri yang dihitung secara mandiri. Serta peneliti juga menghitung teknik lay up dan one hand set shot berdasarkan dari posisi tempat sampel melakukan teknik tersebut dengan maksud peneliti tidak hanya mengetahui hasil tes lay up dan one hand set shot secara keseluruhan.

Berdasarkan deskripsi data pada keterampilan lay up dan one hand set shot peserta ekstrakurikuler bolabasket di SMAN 1 Turen Kabupaten Malang yang berjumlah 20 peserta secara keseluruhan didapatkan peserta paling banyak dalam kategori "Cukup" dengan jumlah 13 peserta $(65,00 \%)$. Hal tersebut dapat diartikan peserta ekstrakurikuler bolabasket di SMAN 1 Turen Kabupaten Malang belum terlatih dengan baik, dikarenakan intensitas latihan yang masih sangat kurang yang dimana latihan dilakukan seminggu hanya 1 kali.

Dapat diketahui saat melakukan teknik dasar lay up peserta ekstrakurikuler bolabasket di SMAN 1 Turen Kabupaten Malang kesalahan sering terjadi untuk kelompok putra saat melempar peserta sering memasukkan bola ke arah ring dengan pergelangan tangan tidak digunakan sebagai dorongan, yang kebanyakan peserta memasukkan bola hanya dengan mendorong bola ke atas menggunakan lengan dan untuk kelompok putri kebanyakan peserta melakukan lay up pada saat menembak posisi bola masih berada di bawah kemudian melemparkannya ke atas tanpa meluruskan tangan ke atas dan tanpa menggunakan pergelangan tangannya.

Sedangkan dalam melakukan teknik dasar one hand set shot peserta ekstrakurikuler bolabasket di SMAN 1 Turen Kabupaten Malang kesalahan sering terjadi untuk kelompok putra saat melakukan tembakan banyak peserta putra setelah mengangkat bola ke atas bola berada di atas kepala yang memungkinkan bola tidak terlihat saat diarahkan ke arah ring dan untuk kelompok putri kebanyakan peserta saat melakukan tembakan bola belum diangkat ke depan atas dahi tetapi bola sudah didorong dan dilempar dari bawah, serta siku tidak tertekuk ke atas yang mengakibatkan bola tidak terdorong dengan baik dan arah bolanya tidak beraturan.

Dari hasil tersebut diketahui perbedaan pemahaman dalam melakukan teknik dasar lay up dan one hand set shot termasuk kurang. Ini dapat terjadi karena kurangnya waktu berlatih dan edukasi dari pelatih dalam melakukan pembenaran yang membuat pemain melakukan teknik dasar lay up dan one hand set shot secara apa yang mereka tahu saja. Kurangnya waktu saat latihan menjadi salah satu faktor untuk mendukung keterlatihan siswa, karena semakin seringkali peserta berlatih maka keterampilan pemain akan terus meningkat dan konsisten dalam melakukan teknik dasar tersebut. Selain dari faktor latihan, tingkat kemampuan tiap individu dengan individu lain dalam melakukan teknik dasar lay up dan one hand set shot berbeda-beda. Karena teknik dasar lay up dan one hand set shot merupakan teknik dasar yang penting dalam permainan bolabasket dan dapat menjadi penentu dalam tiap pertandingan dalam meraih kemenangan yang dimana tiap pemain harus dapat menguasai teknik dasar tersebut dengan baik.

Hal ini diperkuat lagi dengan penelitian yang telah dilakukan oleh Prasetya (2012), mengungkapkan bahwa lay up merupakan teknik dasar yang dikuasai oleh pemain bolabasket sebab teknik ini ialah penentu pada setiap pertandingan bolabasket yang intinya sasaran akhir pada permainan bolabasket adalah mencetak angka.

Serta penelitian yang dilakukan Fitrianto (2015), didapatkan hasil dari berbagai jenis shooting yang dilakukan pemain lebih sering menggunakan teknik one hand set shot untuk memasukkan bola yaitu dari 56 kali percobaan, 17 diantaranya masuk dan sisanya gagal. Berdasarkan hasil penelitian tersebut dapat diketahui 
bahwa teknik one hand set shot sangat penting untuk pemain bolabasket karena seringnya pemain dalam menggunakan tembakan tersebut. Rahim (2015), yang menyebutkan bahwa menembak ialah keahlian yang sangat penting dalam olahraga bolabasket. Teknik dasar seperti operan, menggiring, bertahan, \& rebounding membantu tim dalam memperoleh peluang mendapatkan skor dan harus diakhiri dengan melakukan tembakan ke arah ring, tentu saja salah satunya dengan menggunakan tembakan one hand set shot.

\section{KESIMPULAN}

Berdasarkan hasil penelitian dan analisis data tes keterampilan lay up dan one hand set shot yang telah dilakukan pada peserta ekstrakurikuler bolabasket di SMAN 1 Turen Kabupaten Malang, dapat disimpulkan bahwa keterampilan teknik dasar lay up dan one hand set shot peserta ekstrakurikuler bolabasket di SMAN 1 Turen Kabupaten Malang didapatkan dominan pada kategori "cukup".

\section{DAFTAR PUSTAKA}

Apriani, D. R. (2011). Survei Tingkat Kemampuan Lay Up Dan One Hand Set Shoot Dalam Permainan Bolabasket Pada Kegiatan Ekstrakurikuler Bolabasket Putri SMA N 1 Banjarnegara Tahun 2010/2011. Semarang.

Edwards, T., Spiteri, T., Piggott, B., Bonhotal, J., Haff, G. G., \& Joyce, C. (2018). Monitoring and Managing Fatigue in Basketball. Sports. https://doi.org/10.3390/sports6010019

Febrianto, T. S. (2013). Survei Hasil One Hand Set Shoot Dalam Permainan Bolabasket Pada Pemain Putra Kelompok Usia 12-15 Tahun Klub Basket Sehati Kota Semarang Tahun 2012. Semarang: Universitas Negeri Semarang.

Fitrianto, A. T. (2015). Jenis Penguasaan shooting yang Banyak Menciptakan Point Pada Pemain Bola Basket Putra SMA Kristen Kanaan Banjarmasin. Pengaruh Power Tungkai Dan Kekuatan Lengan Terhadap Kemampuan Standing Jump Shoot Dan Quick Jump Shoot, 1-18.

Hamsa, M., \& Hartoto, S. (2015). Survey Minat Siswa Kelas VII dan VIII di SMPN 1 Bangil dalam Mengikuti Ekstrakurikuler Renang. Jurnal Pendidikan Jasmani, 03(03), 783-788.

Jamshed, S. (2014). Qualitative research method-interviewing and observation. Journal of Basic and Clinical Pharmacy. https://doi.org/10.4103/0976-0105.141942

Kafle, N. P. (2013). Hermeneutic phenomenological research method simplified. Bodhi: An Interdisciplinary Journal. https://doi.org/10.3126/bodhi.v5i1.8053

Kentiba, E., \& Asgedom, T. (2018). Elements Contributing to Limited Participation of Disabled Children in $\begin{array}{lllll}\text { School Based Sport Extracurricular } & \text { Activities. }\end{array}$ https://doi.org/10.11648/j.ijsspe.20170206.11

Leguina, A. (2015). A primer on partial least squares structural equation modeling (PLS-SEM). International Journal of Research \& Method in Education. https://doi.org/10.1080/1743727x.2015.1005806

Lestari, R. Y. (2016). Peran Kegiatan Ekstrakurikuler Dalam Mengembangkan Watak Kewarganegaraan Peserta Didik. Untirta Civic Education Journal. https://doi.org/10.30870/ucej.v1i2.1887

Nathial, M. S. (2014). Analysis of Set Shot in Basketball in Relation with Time to Perform the Course and Displacement of Center of Gravity. American Journal of Sports Science, 2(5), 122. https://doi.org/10.11648/j.ajss.20140205.13

Okazaki, V. H. A., Rodacki, A. L. F., \& Satern, M. N. (2015). A review on the basketball jump shot. Sports Biomechanics. https://doi.org/10.1080/14763141.2015.1052541

Polozov, A., \& Akhmetzyanov, A. (2019). The Technology of Obtaining the Highest Possible Result in the Upcoming Match of Top-Level Basketball Teams. 7(1), 11-19. https://doi.org/10.11648/j.ajss.20190701.13

Prasetia, A. B. (2015). Tingkat Kemampuan Lay Up Shoot Pada Siswa Yang Mengikuti Ekstrakurikuler 
Bolabasket Di SMK Leonardo Klaten. Yogyakarta: Universitas Negeri Yogyakarta.

Prasetya, Y. (2012). Efektivitas Lay Up Shoot Menggunakan Underhead Dan Overhead Pada Sudut 45 Derajat Terhadap Kemampuan Hasil Lay Up Shoot Pada Pemain Bola Basket Putra SMP N 3 Batang Tahun 2012. Semarang: Universitas Negeri Semarang.

Rahim, A. R. N. (2015). Kemampuan One Hand Set Shoot Dengan Jump Shoot Terhadap Efektifitas Mencetak Skor Dalam Permainan Bola Basket di SMA N 1 Pengasih Kulon Progo. Yogyakarta: Universitas Negeri Yogyakarta.

Sumaryoto, \& Sopembri, S. (2017). Pendidikan Jasmani, Olahraga dan Kesehatan SMA/MA/SMK/MAK Kelas $X I$. Jakarta: Kementerian Pendidikan dan Kebudayaan.

Teramoto, M., \& Cross, C. L. (2018). Importance of team height to winning games in the National Basketball Association. 13(4), 559-568. https://doi.org/10.1177/1747954117730953

Tobalina, J. C., Calleja-GonzÁlez, J., De Santos, R. M., FernÁndez-López, J. R., \& Arteaga-Ayarza, A. (2013). The effect of basketball footwear on the vertical ground reaction force during the landing phase of drop jumps. Revista de Psicologia Del Deporte.

Trojian, T. H., Cracco, A., Hall, M., Mascaro, M., Aerni, G., \& Ragle, R. (2013). Basketball injuries: Caring for a basketball team. Current Sports Medicine Reports. https://doi.org/10.1097/01.CSMR.0000434055.36042.cd

Tsang, W. W. N., \& Dkk. (2014). The effect of vestibular stimulation on eye-hand coordination and postural control in elite basketball players. 2(2), 17-22. https://doi.org/10.11648/j.ajss.20140202.12

Van Hoecke, M. (2016). Methodology of Comparative Legal Research. Law and Method. https://doi.org/10.5553/rem/.000010

Yusmawati. (2014). Upaya Peningkatan Hasil Belajar Lay-Up Bola Basket. Journal of Physical Education Health and Sport, 1(2), 77-85. 